\title{
The Concept of an Imperial City in The Modern Global World
}

\author{
Yulia Maltseva ${ }^{1, *}$ \\ ${ }^{1}$ Saint Petersburg State University, Institute of Philosophy, Department of Cultural Studies, \\ Philosophy of Culture \& Aesthetics, University embankment 7-9, 199034, St Petersburg, Russia
}

\begin{abstract}
.
Research background: The author analyzes the phenomenon of cultural identity of the city and its cultural and economic aspects which allows us to create the concept of the Imperial city, and analyze its relationship with its own historical background and ideas about the global city. Structural analysis of modern ideas about the Imperial city allows us to ensure a strong urban brand and influences its global competitiveness.

Purpose of the article: The article is devoted to the problem of forming strong brands of certain territories, in particular, Imperial cities, and their impact on the competitiveness of the region.

Methods: The multidisciplinary approach to the analysis of a chosen phenomenon combining economic-statistical and cultural-philosophical methods to assess the mutual influence of the city's globality and its Imperia concept on the formation of its distinctive ecnomically strong brand.

Findings \& Value added: The analysis showed that a new understanding of the phenomenon of the Imperial city, strengthening its brand, increasing recognition in the world and close ties with cultural dominants allows the Imperial cities to attract significant financial investments and improve their competitive position at the global market. As a scientific growth, the author can consider the influence of the Imperial city concept on the structure of the formation of a successful urban brand of a territory. The author proposes the new methodology for assessing the brand value of the Imperial City.
\end{abstract}

Keywords: the concept of the modern Imperial city; global world; global city; cultural identity

JEL Classification: $R 11 ; Z 10 ; Z 13$ 


\section{Introduction}

Despite the fact that the concepts of empire and Imperial city are firmly fixed in the language of history, the modern situation which presupposes the city as a form of concrete and predominant existence of culture, the concept of an Imperial city needs additional humanitarian understanding - economic, cultural, philosophical.

So, the Imperial city as it entered the language of history, [German. Reichsstadt, in the Holy Roman Empire] is a city subordinates to the emperor himself.

- politically (supply of troops for military campaigns; broad rights of selfgovernment, almost complete political independence in all matters except military)

- legally (participation in the Reichstag)

- $\quad$ economically (paying taxes directly to the emperor)

It existed simultaneously with the free cities, gradually merging into one group of "free Imperial cities".

Historical and political discourses also have a sense of empire; we can even argue that the history of mankind is written as the history of empires that existed on earth. It seems as if the reasons for their existence are obvious and have a solid foundation. Indeed, political reasons (increase in territory, annexation of lands for communication with more distant provinces), military reasons (strategic defensive position of a particular territory) seem to be quite reliable and well described and studied. It may sometimes even seem that the socalled "Imperial consciousness" has been described but here the first difficulties are outlined.

Thus, in his works, Said expresses an important, from our point of view, idea that "preparation for the construction of an empire takes place within culture" [1]. However, the approach proposed by Said seems to us insufficient, since it establishes cause-and-effect relationships between phenomena, which, in our opinion, should be regarded as side by side. The empires of the European countries took shape much earlier than the ideology of Imperial ism. The consolidation of the British Indian Empire proceeded in parallel with the formation of the genre of the English novel, and, accordingly, the political impulse inherent in it could, of course, influence the formation of an explicit Imperial ist ideology, but not Imperial construction itself. The systematized Imperial ist ideology, which has become a fact of public consciousness, according to G. Lightheim's just remark, is taking shape after the fact, "its rise may in reality coincide with the decline of the empire" [2].

If for the Western author (M. Doyle) "an empire is a product of a special interaction between the forces and institutions of the metropolis and the forces and institutions of the periphery" [3], for the Russian it is "a complexly organized universal system.. As such, it is able to exert a balancing effect on the internal contradictions of human nature and functionally use them. The empire not only crushes the personality, but raises the most insignificant of its subjects to the ordinarily unattainable ontological height, orienting itself in space and time" [4]. Another Russian author says that "the creation of an empire is possible only at the high rise of the human spirit" [4], and with the loss of the general idea of an empire, "internal disintegration begins, which will inevitably become an external disintegration" [5].

"The Empire, the Imperial City is an exploratory situation, not a structure, a problem, not a diagnosis. The bottom line is that the analytical tools of modernity are thoroughly "national" and the empire cannot be described within the framework of any one model, with the help of any one metanarrative. Therefore, the empire can be "seen" only by consciously and contextually combining different research optics. The new Imperial history offers a multidimensional perspective on political, social and cultural actors, on the 
"spaces" in which they operate. Thus, the new Imperial history and the Imperial City itself act as an "archeology" understood in the spirit of the post-structuralist Fukian paradigm, deconstructing the basic and normative ideas of the social sciences.

The triumph of the constructivist approach to the "nation", which is recognized by most researchers as a "construct", an "imaginary community", did not affect the "history of empires" in any way, that attempts are still being made to create a "theory of empire", calculate a certain cycle of its development (decline and rebirth ) [6]. Gerasimov and Mogilner propose to study not structures, but practices and discourses that are intertwined in a dynamic open system of the "Imperial situation". The "Imperial situation", in their opinion, "is characterized by the parallel existence of mismatched social hierarchies and value systems, with a very roughly established" exchange rate "of status - while the ideal model of a modern nation-state assumes the universality and equivalence of social categories in all corners of society." [7,8]. This is truly a new step in the study of empires.

For the first time, a methodology is proposed that is applicable specifically to Imperial studies, and this should be considered the most important, perhaps the most important achievement in the entire history of imperiology. On the other hand, it should be noted that this approach is not fundamentally new, it seems to us that it has been developed for a long time on the basis of the "colonial (contact) situation" methodology, designed to establish a framework for studying the relationship between two or more peoples. The "Imperial situation" is characterized by the coexistence of several alternative social hierarchies, with an indefinite or multiple "course of mutual conversion".

\section{Methods}

The empire itself is a fundamentally heterogeneous space. And, based on the above, the convertible currency of the empire is the dynamic interaction of fundamentally homogeneous compounds, in the course of which there are a variety of "coins": the Imperial myth, control over meanings and their generation, the normative nature of the "Imperial instance", etc. This situation gives us a reason to draw up a very special methodology for converting exchange within the empire, and also to highlight such its most important formation as a modern Imperial city.

In the situation with the Imperial City, it is worth noting that in the modern world the role of intangible assets is constantly growing, which is manifested both in the price of goods and services, and in the "investment capital" of such specific objects as territories. The information economy and intellectual capital are becoming more and more important drivers of economic growth. [6,7] In the modern media world, the level of representation of the territory in the network, the information field formed around it and the images reflected in the public consciousness form the myth underlying the brand of the territory.

The problem of developing the intangible assets of territories is directly related to increasing their economic attractiveness and forming a strong attractive brand. Indeed, a formed positive image and a developed brand can provide an influx of various groups of visitors to the territory, including tourists and business visitors, lead to an increase in the investment attractiveness of the territory; create conditions for comfortable living and doing business. Consequently, a branded territory has a chance to be highly recognizable and attractive, and the absence of a brand can lead to a lack of territory in the consumers' "choice list".

The concept of a territory brand is interpreted in very different ways. In particular, various authors such as Ari-Vecco Antiroko [8], Migelis Kawaratzis and Mary Yo Hutch [9], Elina Norvanen, Christina Golding [10], Kevin Line Keller [11], Saskia Sassen [12] suggest considering the Imperial a city as a zone of increased economic attractiveness, because the Imperial City is: 
- City with imperial architecture and imperial image [13];

- City with an imperial mentality, which is shared by residents and all of its stakeholders [14];

- City with a developed institutional infrastructure, iconic and symbolic structures that bind the empire.

The Imperial city itself produces a complex of intangible assets due to its status and special form of existence, namely:

- constructs an original ethos

- polyethnic

- almost always the capital

- $\quad$ sets economic policy

- $\quad$ sets the cultural norm (from linguistic norms and literary genre to fashion)

- forms an aesthetic model, speaks whole genres in art

- constructs a special identity of the citizen

- creates standards of material and spiritual consumption

- constructs a city dweller bodily

- he creates the space of the borderland - himself and within himself

- possesses the external attributes of Imperial ism: not only architecture, urban planning, but also the presence of structures and institutions inherent only to it (opera house, museum, university, main temple, etc.)

We can say that the Imperial city sets in the cultural, social and other planes a kind of measure, in accordance with which the culture of the "empire" is created, developed, and changed. An Imperial city can develop according to this type in a certain period of history, both when it comes to the political and military component, and when, as in the modern situation, it is about the economic circulation of symbols and signs that form the Imperial ism of the city brand. Of course, many cities are not able to maintain the imperial type of development and integrate into the new economy as successfully as others that did not lose the intangible value of their territory due to the collapse of the empire, but, on the contrary, retained their status as a normative and semantic center, retaining a strong influence on the world politics, economics, and individual components of imperial style, infrastructure, or perception.

For a long time Athens was the center of the Greek world, and thanks to the military campaigns and the policies of Alexander the Great, it became the focus of public order and the symbolic perception of the imperial world order. At the same time, with the collapse of the empire of Alexander the Great, plunging into the chaos of the territories transformed by the empire and the division of the new integrated space, Athens lost not only world control, but also its imperial spirit. This city has long lost its imperial function and status [15].

A much more interesting situation concerns Constantinople. The city, which became the center of the Byzantine Empire and took over the functions of Athens and Rome, lost by them after the collapse of the Greek and Roman empires, being captured, at one moment lost the role of an Imperial city. However, in the future, this city again acquired its imperial appearance, style and infrastructure, but already attached to the new empire, the center and focus of which it became already under the modern name Istanbul. The strength of Turkish influence in the world was determined by advanced military technologies, the adoption of cultural functions of Persia, which had lost its world influence, but also in the imperial essence of Istanbul. However, as a result of the revolutionary processes, the Turkish Empire was also shaken. For a long time, Istanbul lost its imperial mentality; the capital of Turkey moved to Ankara, marginal phenomena negatively affected the image of the city and its 
imperial essence. In the middle of the 20th century, the world was horrified by Istanbul after the release of the film "Midnight Express", which showed the abuse of prisoners in Istanbul prisons and the hardships of city life. The city acquired criminal fame for a long time. [16]

Today Istanbul has once again been able to restore its attractive image and regain its imperial mentality. A significant role in this new imperial vision of the city was played by the locals who fell in love with their city and brought this love to all consumer audiences and stakeholders. The new bestseller for the image of Istanbul was the film "City of the Cats", which reflected the attitude of the townspeople towards the furry inhabitants of the city, which make up one of the iconic symbolic structures of modern Imperial Istanbul [17].

But St. Petersburg, born in order to turn the Muscovy into a Russia Empire, became the Imperial City "by birth." Indeed, we can easily distinguish all the criteria by which the Imperial ism of an urban brand is determined:

- St. Petersburg constructs an original ethos

- polyethnic

- was the Imperial capital, and in Soviet and post-Soviet times it seized the status of a cultural capital, a "special city" throughout the country, which appropriated and sacralized cultural discourse instead of church discourse, in which it acts as a fullfledged owner and arbiter;

- $\quad$ sets the economic policy of the region and is itself a special economic entity that implements intangible assets;

- $\quad$ sets the cultural norm (from linguistic norms and literary genre to fashion)

- forms an aesthetic model, speaks in art in whole genres, and is itself an aesthetic phenomenon;

- constructs a special identity of a city dweller ("I am a Petersburger" - primarily);

- creates standards of material and spiritual consumption

- constructs a city dweller bodily

- it creates the space of the borderland - himself and within himself (oh, you are from St. Petersburg! ..)

- it possesses the external attributes of Imperial ism: not only architecture, urban planning, but also the presence of structures and institutions inherent only to him (opera, museum, university, main temple, etc.). [18]

\section{Results}

It should interesting to note that the study of the intangible assets of the Imperial City using the example of St. Petersburg, and their stability in situations of rupture of economic everyday life (COVID-19 pandemic) led to some conclusions.

Firstly, the demand for services related to intangible consumption (for example, visits to museums, operas, the demand for educational services) remained quite high, especially among the leading cultural institutions: the intangible assets of the Imperial City are successfully passing the stress test.

Secondly, prices for intangible goods are showing growth, while there is practically no market reaction.

Thirdly, various cultural activities find more and more options for original promotion of their services, demonstrating both flexible cooperation skills and flexible competitive strategies for promoting their intangible assets.

Fourth, in the conditions of a strong Imperial brand, made up of strong "players" and niche brands work to strengthen the branded Imperial territory, however, they themselves do not create a brand. 
The listed criteria can be used both by institutions of culture, education, science to assess their activities in "regular" and "non-standard" regimes, and by cities proper by the imperial and local authorities to assess their competitiveness in the domestic and world markets of branded territories or be used by state bodies (in including the relevant ministries and departments of the Russian Federation) [19], implementing economic policy in the market of intangible assets. It is preferable that the accumulation of statistical data takes place in a continuous mode, which would impart dynamism to the economic assessment of results and, ultimately, simplify it. [20]

State institutions that control and regulate the market of intangible assets, such as the brand of the Imperial City itself, will be able to use a dynamic assessment of the circulation of intangible assets in a changing situation as a tool for the most appropriate management of such assets - whether by providing support to certain asset holders, or ranking them.

Thus, it is possible to outline and recommend a number of measures that will have a positive effect on stabilizing and increasing the economic return of the territory branded by the Imperial City.

These measures include the following:

1. Creation of favorable conditions for the functioning of individual brand segments in terms of infrastructure;

2. Creation of an attractive tax policy for the segment of intangible assets;

3. Settlement of the administrative and legal framework;

4. Formation of a system of state support for private museums, galleries, universities;

5. Reforming the system of state cultural institutions in order to increase their economic efficiency; [21]

6. Organization of awards, grants and subsidies for operators of intangible assets;

7. Creation of special educational programs for training of professional personnel.

The above measures are designed to help Russian cultural, educational, and scientific institutions not only effectively retain the existing branded economic resource, cope with the current force majeure circumstances of the pandemic, cope with the current problems of the pandemic period, but also get out of this crisis with a strengthened territorial brand of the Imperial City in nationally and internationally.

\section{Discussion}

The introduction of the described tools for managing intangible assets, which are the brand of the territory, in this case, the Imperial City, will significantly reduce the level of turnover in the assessment of value in the field of culture and will help reduce the risks of public policy in determining its financial priorities.

It should be noted that the described criteria do not take into account some factors, namely:

First, the thoughtfulness of government regulation and support measures: each specific cultural sector requires its own methodological approaches, since no operator of intangible assets creates a brand by itself. [22]

Secondly, the highlighted provisions, which are proposed to be used when understanding the regulation of the market for intangible assets, do not take into account possible risks, although they record their exceptional stability. [23]

Thirdly, for a significant period of time, free movement around the world is limited, and, for example, the Imperial brand of St. Petersburg is a way to earn money on incoming tourism. Therefore, it seems reasonable to partially reorient efforts to strengthen the Imperial brand to domestic consumption markets. [24] 


\section{Conclusion}

The first wave of the COVID-19 pandemic did not cause any tangible damage to the Imperial City of St. Petersburg taken for analysis, since the cultural and scientific institutions sacred here did not suffer a decrease in demand for their services. On the other hand, all the components of the imperial brand need to be reinforced by means of a wellthought-out state policy, since they already show an upward trend, the largest Russian cultural institutions have the opportunity to concentrate around themselves areas of attraction of world intangible assets and create the potential for the exit of Russia in general and St. Petersburg, in particular, to a confident position in the world in this area.

\section{References}

1. Said, E. (1993). Culture and Imperialism. New York: Vintage Books (Random House).

2. Lightheim G. (1987). Imperialism. N.Y.

3. Doyle M.W. (1986). Empires. London: Ithaca.

4. Булдаков В.П. XX век. Российская история и посткоммунистическая советология. А. Борфогов (ред.). Российская империя, СССР, Российская Федерация: история одной страны? М., 1993. С. 9.

5. Померанц Г.А. Выступление на семинаре «Закат империи». Восток. 1991. № 5. С. 13.

6. Kamenica, E. (2017). Information economics. Journal of Political Economy, 125(6), 1885-1890.

7. Segerstrom, P.(1991) Innovation, imitation, and economic growth. Journal of Political Economy, 99(4), 807-827.

8. Anttiroiko, A.V. (2014). The Political Economy of City Branding. Routledge, London.

9. Kavaratzis, M., Hatch, M.J. (2013). The dynamics of place branding: an identity-based approach to place branding Theory. Marketing Theory, 13(1), 69-86.

10. Närvänen, E., Goulding, CH. (2016). Sociocultural brand revitalization: The role of consumer collectives in bringing brands back to life. European Journal of Marketing, $50(7 / 8), 1521-1546$.

11. Keller, K.L. (2012). Economic and behavioral perspectives on brand extension. Marketing Science, 31(5), 772-775.

12. Sassen, S. (2005). When National Territory is Home to the Global: Old Borders to Novel Borderings. New Political Economy, 10(4), 523-41.

13. Foroudi, P., Gupta, S., Kitchen, P., Foroudi, M.M., Nguyen, B. (2016). A framework of place branding, place image, and place reputation: Antecedents and moderators. Qualitative Market Research, 19(2), 241-264.

14. Medway, D., Warnaby, G. (2008). Alternative perspectives on marketing and the place brand. European Journal of Marketing, 42(5/6), 641-653.

15. Kotler, P., Gertner, D. (2002). Country as brand, product, and beyond: a place marketing and brand management perspective. Journal of Brand Management, 9(4-5), 249-261.

16. Aghion, P., Jaravel, X. (2015). Knowledge Spillovers, Innovation and Growth. Economic Journal, 125(583), 533-573. 
17. Pashkus, N.A., Pashkus, V.Y., Altunyan, A.G., Protasov, A.Y., Maltseva ,Y.M. (2019). Cultural City Brands and Global Competitiveness. Revista San Gregorio, 36, 197-209.

18. Braun, E., Kavaratzis, M., Zenker, S. (2013). My City - My Brand: The Role of Residents in Place Branding. Journal of Place Management and Development, 6(1), 18- 28.

19. Kavaratzis, M., Hatch, M.J. (2013). The Dynamics of Place Branding: An Identitybased Approach to Place Branding Theory. Marketing Theory, 13(1), 1-18.

20. Keller, K.L. (2012). Economic and Behavioral Perspectives on Brand Extension. Marketing Science, 31, 772-775.

21. Zenker, S., Martin, N. (2011). Measuring Success in Place Marketing and Branding. Journal of Place Branding and Public Diplomacy, 7 (1), 32-41.

22. Govers, R. (2011). From place marketing to place branding and back. Place Branding and Public Diplomacy, 7(11), 227-231.

23. Kliestik, T., Kovacova, M., Podhorska, I., Kliestikova, J. (2018). Searching for Key Sources of Goodwill Creation as New Global Managerial Challenge. Polish Journal of Management Studies, 17 (1), 144-154.

24. Starobinskaya, N.M. (2019). Socio-cultural sphere in the new economy: from the development of education to the art market. St. Petersburg: KultInformPress. 